\title{
Influence of Working Conditions on Turnover Intentions of Secondary School Teachers in Meru County
}

\author{
Peter Kalunge Ekabu (PhD Student) \\ Jeremiah.M.Kalai (PhD) \\ Grace Nyagah (PhD)
}

Department of Educational Administration and Planning,

University of Nairobi, Kenya

Doi:10.19044/esj.2018.v14n25p169 URL:http://dx.doi.org/10.19044/esj.2018.v14n25p169

\begin{abstract}
The objective of this study was to examine the relationship between working conditions and teacher turnover intentions in public secondary schools in Meru County, Kenya. The study used a descriptive survey design with both quantitative and qualitative approaches in data collection and analysis. A total of 520 respondents were involved in the study that included 503 secondary school teachers, 15 principals and 2 staffing officers. Teachers working conditions were examined to determine their relationship with turnover intentions. Data obtained from teachers' questionnaires were analyzed quantitatively using SPSS version 21.Hypotheses were tested using Pearson product moment correlation coefficient and chi-square goodness of fit at $95 \%, \mathrm{p}<0.05$.

The result of product moment correlation analysis indicated that the independent variable, working conditions $(r=-0.488, p<0.001)$ have a negative and an inverse relationship with the independent variable, turnover intention. These results were agreed with the results of Chi-square analysis for both the independent variable which showed a significant relationship between working conditions and turnover intentions of secondary school teachers in Meru County. The results therefore established that teachers' motivation in secondary schools in Meru County is low due to poor working conditions and the education system appears to be staffed with teachers with poor morale and low levels of commitment to their jobs leading to high turnover intentions. The study recommends the various Boards of Management and other education stakeholders at the national and county government levels consider issues of teachers working conditions as an essential element in the motivating and reducing turnover intentions hence retention in teaching service.
\end{abstract}


Keywords; Motivation, Turnover intention, working conditions

\section{Background}

Literature available indicates that teacher turnover leads to the following school problems. First, it leads to weakening of school cohesion undermining performance of such schools in national examinations (Ingersoll, 2001; \& Guin, 2004). Second, turnover leads to disruption of instructional programs for schools (Johnson, Kraft \& Papay, 2012). Third, it leads to shortage of teachers forcing schools to hire substitute teachers leading to incoherence in delivery of curriculum content (Shields, Esch, Darling-Hammond and Luczak, 2005). Fourth, a high teacher turnover leads to low quality education by weakening of quality teaching (Loeb et al, 2005). Fifth, a high teacher turnover erodes the schools' financial strength through allocation of extra funds for employing new teachers (Loeb, Darling-Harmond and Luczak, 2005).

Turnover intention according to Souza- posa, \& Hennenberger (2004) is a conscious as well as deliberate willfulness to quit an organization and it is a major precedent of actual turnover. Purani and Shadev (2007) defines turnover intention as a plan by an employee to leave the current job to another in near future. It is the probability that an employee will quit his or her current job within a stipulated period of time leading to actual turnover (Kaur, Muhindra \& Pankaj, 2013). Suleiman and Matson (2013) on other hand argues that turnover intention determines turnover as it is the crucial stage before occurrence of actual turnover in an organization. According to Krishnan \& Singh (2010), turnover intention among teachers' results in low motivation in their work thus impending school goals. This is because employees (teachers) intending to move to perceived favorable work or areas show low excitement with their current work activities (Quick \& Nelson, 2011).Apart from high cases of absenteeism, workers intending to move to another job or to transfer to another work place are usually in conflict with the management, leading to disciplinary action ( Jong \& Gutteling, 2006). Tarmizi (2008) assert that turnover intention in an organization erodes the commitment level of other employees in the same organization hence organizations should take strategic steps to reduce turnover intentions of their employees.

In Kenya just like the continental and global trends, teacher turnover is high (Orodho, Waweru, Ndichu, \& Nthinguri, 2013). Available data show a serious shortage of teachers in Kenyan secondary schools with a large number of such teachers leaving the teaching profession for non-teaching related jobs in both private and public sector (Oketch, \&Ngware, 2012; Orodho et al, 2013; Susu,2008). Researchers have identified that deplorable working conditions, among other factors, have created a lot of despair amongst Kenyan teachers and many of them would quit teaching if an opportunity arises (Achoka, Popoi, $\&$ Sirma, 2011; Kafu, 2011).Though various studies in Kenya have attempted 
to solve the problem of teacher retention, job satisfaction, and actual turnover, the simultaneous relationship between motivation and intention to quit teaching have seldom been researched. The government has attempted to solve turnover problems by increasing recruitment efforts, and harmonizing teacher's salary with those of other public workers, but this strategy has never granted the desired outcomes hence teachers' turnover still persists.

\section{Objective}

The objective for this study was to examine the relationship between working conditions and teacher turnover intentions among secondary school teachers in Meru County.

\section{Null hypothesis}

There is no significant relationship between working conditions and turnover intentions of secondary school teachers in Meru County,Kenya

\section{Literature Review: \\ Relationship between working Conditions and employees turnover intentions}

Working conditions are some of the most important factors that influence employee's decision to either leave or remain in an organization. This is because as noted by scholars Zeytinoglu and Denton (2008), people feel comfortable working in organizations with positive work environment. In such organizations, employees feel they can make a difference as the working conditions are conducive (Zeytinoglu \& Denton, 2008).Juliet (2010) asserts that working conditions such as physical and psychological factors within a job are important motivators and where such motivators are lacking, employees will quit their current jobs. Teacher turnover intentions are influenced by certain working conditions they do not like such as low levels of remuneration, large class sizes, poor administrative support, bad school facilities, long distances to commute to schools, not being involved in school's decision making process (Henkins, \&Holliman, 2009; Horg, 2009).

According to Gasinzi, Jesse and Makewa (2013), teachers need to be motivated for them to perform and that their motivation is influenced by various factors including the nature of school infrastructure, the amount of salary, professional status, level of achievement, opportunities for further learning, relations with others, the type of school policies and leadership and working conditions which also increase job commitment and lower turnover intentions. Sergiovanni (2009) concurs by arguing that effective schools that strive to create a conducive environment, that enable teachers to perform their tasks, participating in decision making, have autonomy in their work, have recognition, given respect, work well with other colleagues and are provided 
with opportunities for self-development hence result in teacher commitment, creativity and work persistence reducing turnover intentions. Parasuraman, Uli, and Abdulla (2009) posit that most of worker's life is spent in work places hence such places should be pleasant as unpleasant work environment affects not only work life but also other parts of human life. Therefore, organizations should create work environment that motivate, attract and retain hardworking individuals to be able to have competitive advantage. (Parasuraman, Uli, \& Abdulla, 2009).

Workers (teachers) are happy to work in organizations that provide flexible work schedules, time off, child care assistance and parental leaves (Roberson \& Elis, 2008). The results of the study show a greater organizational commitment, and lower intent to renounce their profession if employees got access to work life policies. Employees usually try to avoid working in places which are tiring, are poorly lit, and are hot or very cold and generally unpleasant (Nyamubarua, 2013).Literature available shows that teaching is one of the most stressful jobs. For example, in Scotland, Finlayson (2003) noted stress as the major cause of health problems among teachers, teacher turnover, absenteeism among teachers, and other teaching related problems making the government to spend about 43 billion pounds a year. At the same time, stress among teachers was observed to have been caused by high workload, conflict at work, and pupils discipline problems. Jesus and Conboy (2001) posit that though motivation of teachers is important for work performance, research has found that teachers are lowly motivated and have high levels of stress than other professions leading to many teachers thinking of leaving their jobs.

Research shows that when employees are overburdened and dissatisfied with their work and their employers, they suffer a lot of mental and physical disorder which include a lot of stress, muscle and joint stiffness, high tension and depression, a lot frustration, lethargy in work as well nervousness and insomnia resulting to high turnover intentions (Frese, 1985).Conversely, when employees' level of satisfaction is high, such employees' hold high attitude towards the job unlike an unsatisfied employee who holds negative attitude towards work (Waleed,2013).This therefore implies that satisfaction of employees' is an important step in sustaining them in an organization and ensuring they are loyal to their jobs and the organization. Studies have revealed that adverse working conditions usually lead to job dissatisfaction amongst employees eventually leading to quitting their jobs (Handelsman, 2009). For example, some geographical locations of schools are very harsh for teachers. These schools include those in arid and semi arid areas as well as those in poorly drained areas such as marshy, as well as disease prone areas with very poor infrastructure. Teachers would work in such areas because of desperation for a job and income but when financial stability is achieved by these teachers, 
they would move to other better places or even continue seeking transfer to more endowed schools (MacDonald, 2012).

Mampane (2012) alludes that if employees (teachers) have a negative attitude or negative perception of their workplace, they are more likely to be absent from work, have increased stress related sicknesses, as well as declined productivity and commitment to their work (teaching). Conversely, in organizations where there is friendlier, trusting, and safe environment, greater productivity, creativity and financial stability are experienced (Mampane, 2012).

The nature of relationship between an employee and the management can lead to such employee either being motivated to remain or leave an organization altogether. If a supervisor has positive attitude towards a subordinate and treats him/her well, then the employee will remain in the organization and the reverse is true (Ng'ethe, 2012; Mbah \& Ikemefuna, 2011). Farren, (2008) found out that managers who valued, respected and supported employees' competency, paid attention to their problems, and needs, gave challenging work, valued employees' work, and provided learning opportunities and ensured employees are engaged, resulted to motivation of such employees hence little or no intention to leave thus enhancing retention. According to Harris, Harris and Eplion (2007), supervision involves the attitude of employees towards their immediate supervision and contends that negative perception about supervision lead to job dissatisfaction, poor job commitment and turnover intentions. On the other hand, a positive supervisoremployee relationship leads to a two way communication between the supervisor and the employee ensuring trust as well as increasing performance, job satisfaction, organizational commitment and lower turnover intentions. Employees would prefer to work in an environment that allows free interaction with other colleagues, subordinates and their supervisor. This creates a sense of comradeship and teamwork within the organization leading to motivation in working (Khan\& Qadir, 2016).

Literature available indicate that employees (teachers) are happy with supervisors (principals) who understand and take care of their needs, provide them with necessary support in their work and treat them fairly and equitably (Khan \& Qadir, 2016). Conversely, supervisors (principals) who are indifferent and display arrogance towards their subordinates lead to demotivation of such workers (teachers) resulting to poor organizational (school) performance and high levels of turnover intentions. Additionally, employees who receive managerial support either formally or informally feel valued and respected leading to productive behaviors such as low absenteeism, more job involvement and commitment and generally a reduced intention to quit the job (Khan \& Qadir, 2016). 
According to Freyermuth (2007), employees who might have a good academic background and good certificates, with excellent skills and who might find a lot of job opportunities elsewhere, might be compelled to remain with their present organization if there is good work environment and a strong bond with the manager resulting in reduced turnover intentions in such organizations. Therefore, it is imperative for managers (principals) to go an extra mile even beyond their normal working hours to help subordinates (teachers) cater for their private needs to create cohesiveness at work places as this reduces turnover intentions (Khan \& Qadir, 2016). Kim (2002) concurs by stating that managers who use effective supervisory communication lead to increased job satisfaction hence low turnover intentions amongst their subordinates. Literature available indicates that when employees are involved in decision making by management, job satisfaction is enhanced which reduce turnover intentions. Research shows that organizations which involve their employees in finding solutions to problems of their organization through operating in a transparent manner are able to retain such employees during times of economic recession or downturn as such employees feel part of the solution and not a problem (Ongori, 2008).

\section{Methodology}

Cross-section survey design was used in this research. Primary quantitative data was collected through a teacher questionnaire. This was augmented by primary qualitative data collected from secondary school principals through interviews based on an interview guide. All secondary school teachers including all the principals in public secondary schools in Meru County were involved in the study. Meru County has a total of 367 public secondary schools and a total of 2582 teachers employed by the Teachers Service Commission.

Using a stratified proportionate sampling method, twenty percent of the schools used for the study in each sub-county were selected based on the number of schools in each sub-county as proposed by Gay, Mills, \&Airasian (2009), and Mugenda and Mugenda (2003) who contend that social researchers recommend that 10 percent to 30 percent of the accessible population is enough and at least 30 cases are required per group for statistical data analysis. Based on this, 73 secondary schools (55 day and 18 boarding) which are 20 percent of the total number of schools were used in the study. With a total population of 2,582 teachers in Meru County, the sample size was determined through the same method leading to a sample of 516 teachers. According to Alreck and Settle (2004), a sample size of 100 cases is necessary for statistical data analysis. At the same time, the researcher interviewed 15 principals of secondary schools in Meru County who were randomly chosen from 73 secondary schools sampled for the study. 
Responses were sought for a set of attributes for each specific objective using a Likert scale with 1-Strongly agree (SA), 2-Agree (A), 3- Neither agree nor disagree (ND), 4-Disagree (D) and 5-Strongly disagree (SD). The values were recorded to with 5-Strongly agree, 4-Agree, 3-Neither agree nor disagree, 2-Disagree and 1-Strongly disagree during data analysis. Cronbach's alpha was used to measure internal consistency of the questionnaires. A Cronbach's alpha value $(\alpha)$, statistical tool, equal or greater than 0.7 were acceptable as a good measure of reliability. The Cronbach's Alpha value, $(\alpha)$, obtained was 0.838 which was considered very highly reliable.

Means and standard deviations for each item used to measure teacher working conditions as well as teacher turnover intention were computed using SPSS 21. An aggregate index of the items used to measure working conditions was developed. This was also done for all the items used to measure teacher turnover intentions. Inferential statistics were also computed in the second stage of data analysis to test the stated hypothesis of the study. Chi-square goodness of-fit and Pearson Product-Moment Correlation Coefficient (r) were used to test hypotheses at 95 percent level of confidence and 5 percent level of precision. Chi-square was used to determine the significance levels of relationships between variables. According to Saunders et al (2009), a Chisquare test helps a researcher to establish how likely the two variables are associated. Pearson product moment correlation (r) was used to determine or test the strength and direction of relationship between variables. This is because Pearson Product Moment Correlation Coefficient (r) is a very useful statistical tool in testing the strength of relationship of the study variables as proposed by many authors such as (Mugenda \& Mugenda, 2003; Saunders et al, 2009).

\section{Results and discussions}

The objective of the study was to examine the relationship between working conditions and teacher turnover intentions among secondary school teachers in Meru County. Eleven items were used to study this variable. The results indicated that secondary school teachers in Meru County were moderately satisfied with the working environment with an average mean rating and standard deviation of 2.94 and 1.196 respectively. The results are shown in Table 1. 
Table 1 Relationship between working conditions and teacher turnover intentions

\begin{tabular}{|c|c|c|c|c|c|c|c|c|}
\hline & Mean & SDev & $\mathrm{N}$ & $\begin{array}{l}\text { SA } \\
(\%)\end{array}$ & $\begin{array}{l}\mathrm{A} \\
(\%)\end{array}$ & $\begin{array}{l}\text { ND } \\
(\%)\end{array}$ & $\begin{array}{l}\mathrm{D} \\
(\%)\end{array}$ & $\begin{array}{l}\text { SD } \\
(\%)\end{array}$ \\
\hline I am satisfied with my teaching workload & 2.90 & 1.296 & 497 & 9.3 & 34.4 & 11.5 & 27.0 & 17.7 \\
\hline I am happy with discipline of my students & 2.76 & 1.285 & 497 & 7.8 & 28.9 & 15.7 & 26.7 & 20.9 \\
\hline $\begin{array}{l}\text { I am satisfied with performance of students in } \\
\text { my station }\end{array}$ & 2.19 & 1.107 & 497 & 2.0 & 15.9 & 13.1 & 37.2 & 31.8 \\
\hline $\begin{array}{l}\text { There is a lot of co-operation of colleagues in } \\
\text { my work station }\end{array}$ & 3.32 & 1.195 & 497 & 13.5 & 41.7 & 18.3 & 15.9 & 10.5 \\
\hline I am satisfied with the facilities in this school & 2.60 & 1.211 & 497 & 5.0 & 25.1 & 15.5 & 33.5 & 20.9 \\
\hline $\begin{array}{l}\text { The communication channels in this school are } \\
\text { good }\end{array}$ & 2.89 & 1.126 & 497 & 4.6 & 31.5 & 26.3 & 24.3 & 13.3 \\
\hline $\begin{array}{l}\text { The school management addresses welfare of } \\
\text { teachers }\end{array}$ & 3.06 & 1.147 & 497 & 7.0 & 36.6 & 24.5 & 20.3 & 11.7 \\
\hline My principal treats everyone well & 3.32 & 1.156 & 497 & 14.1 & 37.0 & 25.0 & 15.1 & 8.7 \\
\hline $\begin{array}{l}\text { The school management involves the staff in } \\
\text { decision making, problem solving and policy } \\
\text { making in the school }\end{array}$ & 2.98 & 1.222 & 497 & 9.3 & 32.6 & 18.5 & 26.4 & 13.1 \\
\hline Public relations of my principal are exceptional & 3.09 & 1.205 & 497 & 12.6 & 30.0 & 22.2 & 25.0 & 10.2 \\
\hline $\begin{array}{l}\text { The principal of this school delegates some } \\
\text { roles to teachers hence bringing high motivation }\end{array}$ & 3.23 & 1.205 & 497 & 13.5 & 37.4 & 17.7 & 21.9 & 9.5 \\
\hline
\end{tabular}

Descriptive results in table 1 indicate that 43.7 percent of the respondents strongly agreed and agreed they were satisfied with the teaching workload while a sizeable number, 34.7 percent of the respondents disagreed and strongly disagreed with 11.5 percent of the respondents not committal. The mean rating for this item was 2.90 and a standard deviation of 1.26 meaning that a large number of teachers in secondary schools in Meru County are satisfied with the teaching workload in their institutions implying that teaching workload might not be an issue of teachers turnover intentions in the county. However, a significant number (34.7 percent) were not comfortable with their workload meaning that workload is still an issue to quite a number of teachers leading to turnover intentions. Meanwhile the undecided (11.5 percent) of the respondents means that such teachers can go either way depending on what happens in the schools in terms of staffing and student enrollment. The descriptive results also show that 36 percent of the respondents strongly agreed and agreed that they were happy with discipline of their students while (47.6 percent) strongly disagreed and disagreed with this statement, with 15.7 percent being not sure. The mean rating for this item 2.76 and standard deviation 1.285 implying that majority of the teachers in Meru County are not happy with the discipline of their students hence a major source of dissatisfaction and turnover intentions.

The results also indicate that 69 percent of the respondents disagreed and strongly disagreed that they were satisfied with the performance of their students, with only 17.9 percent of the respondents agreed and strongly agreed while at the same time, a notable 13.1 percent were not sure. The mean rating 
of this item of this item was 2.19 and standard deviation of 1.107. This implies that most of secondary school teachers in Meru County are not happy with the results of their students leading to low motivation and intention to leave to leave teaching. The descriptive results in table 1 also show that a simple majority (55.2) percent of the respondents strongly agreed and agreed that there is a lot of co-operation among teachers in their schools while a sizeable number (26.4 percent) strongly disagreed and disagreed with 18.3 percent being neutral. The mean rating for this item is 3.32 and standard deviation of 1.195 implying that there is a lot of teamwork in their schools hence a lot cooperation is not a major issue of secondary school teachers turnover intentions in Meru County.

According to descriptive results 54.4 percent of the respondents disagreed and strongly disagreed that they were satisfied with the facilities in their schools while a notable number (30.1 percent) agreed and strongly agreed with 15.5 percent of the respondents not sure. The rating mean for this item was 2.60 and standard deviation of 1.211. The results therefore conclude that majority of schools in Meru County have poor facilities implying that teachers are not comfortable teaching in such schools hence would move if they get a chance of joining other schools with better facilities. However, a significant (30.1 percent) were happy with the facilities in their schools implying that facilities could not possibly be a factor that could influence them to leave teaching. These teachers are mainly those teaching in national, extra-county and county boarding schools as such schools have better facilities. The results from Table13 also show that 36.1 percent of the respondents agreed and strongly agreed that there are good communication channels in their schools (37.6 percent) disagreed and strongly disagreed. A sizeable number of the respondents (26.3 percent) were not sure. The mean rating for this item was 2.89 and standard deviation of 1.126. These results show that a sizeable number of schools have no clear channels of communication implying that teachers in such institutions are not very happy with the communication channels between their principals and teachers. However, a significant (36.1 percent) of the respondents have good communication channels hence teachers are happy with the principals in such schools. The undecided ( 26.3 percent) could be swayed either way.

The descriptive results also indicate that 43.6 percent of the teachers agreed and strongly agreed that the school's management addresses their welfare while a notable 32 percent of the teachers disagreed and strongly disagreed with a sizeable number, 24.5 percent not sure. The rating mean for the item was 3.06 and standard deviation of 1.147 implying that majority of the teachers in Meru County are satisfied with their school management's ability to address their welfare hence could not possibly be a reason for intention to leave. However, a sizeable no. (32 percent) are not happy with 
their school management's ability to address their welfare with another 24.5 percent undecided which could alter this situation. A simple majority of the respondents (51.1 percent) agreed and strongly agreed that their principals treat them well while at the same time, 23.8 percent of the respondents disagreed and strongly disagreed. A notable no, 25 percent not being sure. The mean rating for this item was 3.32 and standard deviation of 1.156 implying that secondary school teachers in Meru County are happy with their principals hence could not possibly be a reason for turnover intentions. The results therefore show that many secondary school teachers in Meru County have a lot of confidence with their principals and therefore since their principals treat them well, this could have motivated them to continue working in their current institutions.

The results also indicate that 41.9 percent of the respondents agreed and strongly agreed that their school managements involve teachers in decision making, problem solving and policy making, while 39.5 percent disagreed and strongly disagreed. 18.5 percent of the respondents were not sure. The results therefore show that there is almost a statistical tie between those teachers in Meru County who are happy with the school's management involvement of teachers in school management affairs and those who are not at 41.9 percent and 39.5 percent respectively. The mean rating for this item was 2.98 and standard deviation of 1.22 implying that most secondary school teachers in Meru County were satisfied that their principals involve them in decision making and management of their institutions.

The results also indicate that 32.6 percent of the respondents agreed and strongly agreed that public relations of their principals are exceptional with 35.2 percent disagreeing and strongly disagreeing. A notable 22.2 percent of the respondents were not sure. The mean rating for this item was 3.09 and standard deviation of 1.205 implying that more half of the teachers Meru County rate their principals public relations skills are exceptional hence a major motivator of teachers in such schools. A simple majority (50.9 percent) of the teachers strongly agreed and agreed that their principals delegated some roles to them leading to high motivation of teachers, while a notable (31.4 percent) of the respondents strongly disagreed and disagreed. A sizeable number (17.7 percent) were not sure. The mean rating for this item was 3.23 and standard deviation of 1.205 meaning that most teachers are satisfied with their principals for delegating some duties to them. Therefore, the responses in this variable were a mixed bag with huge oscillations between strongly agrees to strongly disagree. Of great significance is the 37.2 percent who are dissatisfied with the performance of the students in their schools. There is a great indication of team spirit and cooperation among teachers with a significant 41.7 percent strongly agreeing and agreeing that is a lot of 
cooperation among the colleagues in the work station and only a small percentage not agreeing.

The qualitative results of the interview with the principals agreed with the findings recorded in table 1 above. They felt that, although most secondary schools have tried to improve on school infrastructure, most teachers are not happy with these schools and would change their work environment if a chance occurred. For example, the issue of poor performance, indiscipline of students, poor teaching and learning materials is a major concern for most teachers. This makes teachers be frustrated as they are unable to meet society's expectations of good performance hence a lot of demotivation, making them hate the job and therefore eager to move out of teaching at any opportune time. This is in agreement with Mwamwenda (1995) who reported that teachers were demotivated and concerned about inadequate teaching and learning materials. He conducted a study on job satisfaction among secondary school teachers in Transkei, South Africa and concluded that teachers' positive feelings about their working conditions enhanced their work, which promotes attachment to their job and the school.

One principal had this to say:

There are many problems in these newly established day secondary schools.

Proper requirements were lacking when the schools were started. The government does not focus on how students learn or whether or not there are good classrooms, libraries, laboratories or learning and teaching materials. It first encourages communities to start a school by erecting sub-standard buildings or adopting some existing primary school classrooms. There are not enough teachers and poor working conditions. This makes existing teachers be always looking for transfer to more to endowed schools.

Generally, these results are in agreement with literature reviewed. Henkin and Holliman (2009) and Horg (2009) for example reported that teacher turnover intentions are influenced by certain working conditions they do not like such as low salaries, large class sizes, poor administrative support, bad school facilities, large distance to commute to schools, not being involved in school's decision making process and poor working environment. Gesinzi and Makewa (2013) concurs by arguing that teachers need to be motivated to perform and their motivation is influenced by among other factors the nature of school infrastructure, the type of school policies and leadership and good working conditions. Where these are lacking, there is low commitment to teaching and high turnover intentions. Sergiovani (2009) also agrees by alluding that effective schools that strive to create a conducive environment that enable teachers to perform their tasks, participate in decision making, have autonomy in their work, are recognized and respected at work, work well with colleagues and provide opportunities for self-development, result in teacher commitment, creativity, job persistence therefore reducing turnover intentions of such teachers. A study by Gyezaho (2014) observed that lack of facilities 
like piped water, electricity, lack of teaching material, lack of furniture and enough classrooms as sources of turnover intentions for teachers.

Evidence available shows that teachers good relations with their supervisors and co-workers enhance job satisfaction (Sirma\&Poipoi, 2010; Wasserman \& Yehoshua, 2016). In particular, Wasserman and Yehoshua postulate that lowering of supervisory pressure on teachers improves their teaching and strengthens co-operation of teachers with administrators and their work colleagues. Teachers are willing to work hard if they are satisfied with their friendship with co-workers, students, parents, and the respect they received from communities which lead to moral satisfaction of their profession and more morale and less turnover intentions. One principal had this to say;

Teachers are happy and satisfied when they see their learners excel in their performance. If students pass, teachers are happy and if they fail, teachers are affected and are seriously demotivated and demoralized. If poor performance persists, some would not hesitate to leave such schools immediately they get a chance.

Most of the principals reported that teachers in remote rural schools seek for transfer because such schools do not have electricity, water, school houses among other social amenities. However, some teachers are transferring to some of the rural schools to get hardship allowance to enhance their salaries. Concerning remote rural schools one principal had this to say;

Teachers are not eager to teach in some of these rural schools which are located in remote areas where accessibility and means of transport are very poor.

Teachers have to walk long distance to school and no incentives like house allowance to motivate them. The facilities in such schools are seriously lucking and the little that are there are poorly maintained because of luck of funds. This seriously demotivates teachers to continue teaching in such schools and would be more than happy to quit their jobs if they get an opportunity elsewhere or would be seriously seeking transfer from such a school to a better one leading affecting learning.

This is in agreement with Buckley (2004) who concluded that teachers are more likely to quit the profession if they are dissatisfied with school infrastructure, poor transport and long distance to schools compared to their dissatisfaction with salaries. Foljimi (2009) concurs by asserting that distance from schools and safe working environment play an important role in teachers decision to stay or leave the profession. The second part of data analysis involved generation of inferential statistics for this variable through testing of research hypothesis.

\section{Test of hypothesis}

The null hypothesis was: There is no significance relationship between working conditions and turnover intentions of secondary school teachers in Meru County was tested using Pearson Product- Moment Correlation Coefficient and Chi-square goodness of fit at 95 percent level of significance 
and 5 percent level of precision. The null hypothesis suggests that the independent variable, working conditions and the dependent variable, turnover intention is independent of one another. The researcher was interested in finding out whether there was any relationship between working conditions and turnover intentions of secondary school teachers in Meru County. Pearson Product Moment Correlation Coefficient (r) was used to test the strength and direction of relationship between the independent variable (working conditions) and the dependent variable (turnover intention) while chi-square was used to determine the significant level of relationship between the two variables, the independent and the dependent variable. The correlation results are as shown in Table2.

Table 2. Pearson Correlation between working conditions and teacher turnover intentions.

\begin{tabular}{lcc}
\hline & WC & ITL \\
\hline WC - Pearson Correlation & 1 & -.488 \\
Fig (2-tailed) & .000 & .000 \\
N & 502 & 502 \\
TL Pearson Correlation & -.488 & 1 \\
Fig (2-tailed) & .000 & .000 \\
N & 502 & 502
\end{tabular}

The results indicate a significant and negative correlation $(\mathrm{r}=-0.488$, $\mathrm{p}<0.001)$. This means that the working conditions and teacher turnover intentions among secondary school teachers in Meru County have a significant negative correlation. This implies that an improvement in teachers' working conditions corresponds with an equal decline in secondary school teachers turnover intentions in Meru County and vice versa. These findings are in agreement with the findings by Khan and Qadir (2016) who found a significance inverse relationship $(r=-0.813, p<0.01)$ between working environment and teacher turnover intentions in Bahria schools and colleges at Karachi, Pakistani. These results are also in agreement with Zahra et al(2013) who found a significant relationship between work life policies and turnover intentions $(\mathrm{r}=-0.41, \mathrm{p}=0.00)$ meaning that those organizations that are able to integrate their policies with employees' work and life demands are able to lower turnover intentions and vice versa. Literature reviewed in this study shows that employees feel they can make a difference when the working conditions are conducive (Zeytinoglu\& Denton, 2008; Juliet, 2010).

Working conditions such as physical and psychological factors within a job are important motivators and where such motivators are lacking, 
employees will quit their current jobs (Juliet, 2010). The correlation results agree with the literature that as working conditions improve, the turnover intentions reduce. Literature available indicate that turnover intentions are influenced by certain working conditions they do not like such as large class sizes, poor administrative support, poor school facilities, not being involved in decision making etc.(Henkins\& Holliman, 2009; Horg, 2009).

\section{Chi-square analysis for working conditions and teacher turnover intentions}

The results of test of hypothesis by chi-square for working conditions as shown in table 3 concur with the results of Pearson Product Moment Correlation by showing that the Pearson Chi-Square of 87.226 with 4 degrees of freedom and associated p-value (Asymptotic significance) was 0.000 which is very highly significant at $p<0.005$ leading to rejection of the null hypothesis and concluding that there is a significant relationship between working conditions and turnover intentions of secondary school teachers in Meru County. This implies that an improvement in working conditions for secondary school teachers in Meru County will lead to increased job satisfaction and motivation resulting to reduced turnover intentions. These findings agree with the findings of Odunlade (2012) and Muguongo (2015) who found a significant relationship between working conditions and job satisfaction. The results also agree with the findings by Mba and Ikemefuna (2012) that the higher the satisfaction with the nature of work, the lower the employee turnover intention.

Table3 Chi-square results for the working conditions and teacher turnover intentions Crosstab

\begin{tabular}{|c|c|c|c|c|c|c|}
\hline & \multicolumn{6}{|c|}{ WC.Cat } \\
\hline & & & Low & Medium & High & Total \\
\hline \multirow[t]{9}{*}{ ITL.Cat } & \multirow[t]{3}{*}{ Low } & Count & 3 & 7 & 31 & 41 \\
\hline & & $\%$ within ITL.Cat & $7.3 \%$ & $17.1 \%$ & $75.6 \%$ & $100.0 \%$ \\
\hline & & $\%$ within WC.Cat & $1.6 \%$ & $4.7 \%$ & $19.0 \%$ & $8.2 \%$ \\
\hline & \multirow[t]{3}{*}{ Medium } & Count & 9 & 29 & 47 & 85 \\
\hline & & $\%$ within ITL.Cat & $10.6 \%$ & $34.1 \%$ & $55.3 \%$ & $100.0 \%$ \\
\hline & & $\%$ within WC.Cat & $4.7 \%$ & $19.6 \%$ & $28.8 \%$ & $16.9 \%$ \\
\hline & \multirow[t]{3}{*}{ High } & Count & 179 & 112 & 85 & 376 \\
\hline & & $\%$ within ITL.Cat & $47.6 \%$ & $29.8 \%$ & $22.6 \%$ & $100.0 \%$ \\
\hline & & $\%$ within WC.Cat & $93.7 \%$ & $75.7 \%$ & $52.1 \%$ & $74.9 \%$ \\
\hline \multirow[t]{3}{*}{ Total } & & Count & 191 & 148 & 163 & 502 \\
\hline & & $\%$ within ITL.Cat & $38.0 \%$ & $29.5 \%$ & $32.5 \%$ & $100.0 \%$ \\
\hline & & $\%$ within WC.Cat & $100.0 \%$ & $100.0 \%$ & $100.0 \%$ & $100.0 \%$ \\
\hline
\end{tabular}




\begin{tabular}{llll}
\hline Chi-Square Tests & & & \\
\hline & & & $\begin{array}{l}\text { Asymptotic } \\
\text { Significance (2- } \\
\text { sided) }\end{array}$ \\
\hline Pearson Chi-Square & Value & df & .000 \\
Likelihood Ratio & $87.226^{\mathrm{a}}$ & 4 & .000 \\
Linear-by-Linear Association & 91.341 & 4 & .000 \\
N of Valid Cases & 78.437 & 1 & \\
\hline
\end{tabular}

a. 0 cells $(0.0 \%)$ have expected count less than 5 . The minimum expected count is 12.09 .

\section{Summary}

The quantitative descriptive results from the questionnaires show that majority of teachers are not happy with the working environment or conditions in their schools and therefore would leave teaching if they got a better job. However, a large number of respondents were happy with some aspects like favorable workload, being involved in decision making, being well treated by their principals and workplace relations. These results were corroborated by the qualitative results of the interviews with the principals who reported that teachers are not happy with discipline of their students, lack of physical facilities, and poor students' performance among others. This has led to low teacher motivation and high turnover intentions.

The inferential statistics results (Pearson's Product-Moment Correlation) also indicate that working conditions and teacher turnover intentions among secondary school teachers in Meru County have a significant negative (inverse) correlation $(\mathrm{r}=-0.488, \mathrm{p}<0.001)$. This means that an improvement in teachers' working conditions corresponds with an equal decline in turnover intentions of public secondary school teachers in Meru county. The Pearson Chi-Square test hypothesis (87.226 with 4 degrees of freedom, $\mathrm{p}=0.000$ ) also corroborates by concluding that there is significant relationship between working conditions and turnover intentions of secondary school teachers in Meru County. This therefore means that an improvement in working conditions for teachers reduces turnover intentions and increases teacher retention in schools and vice versa. These results therefore concur with literature reviewed for this study which indicated that working conditions play a big role in influencing turnover intentions of secondary school teachers among other employees in other organizations..

\section{Conclusion}

The working conditions (independent variable) has a negative and inverse relationship with teacher turnover intentions (dependent variable).The results of chi-square test of hypothesis also corroborate the results of Pearson product moment correlation (r) which indicates that the null hypotheses was rejected and the alternative hypotheses adopted. The working environment 
with dilapidated school buildings, overcrowded classrooms are largely unsatisfactory and disincentives for teacher retention. Evidence from the research show that there is a lot of motivational problems for teachers in Meru County occasioned by poor working conditions in secondary schools. Hence Teachers are always searching for new jobs or looking for transfers from one school to another affecting schools' performance. In most of schools, buildings are largely dilapidated and classrooms are overcrowded. New government policies such as introduction of performance appraisal and performance contracting have only served to make matters worse for teachers in terms of job satisfaction, motivation and turnover intentions.

\section{Recommendations}

The Board of management of schools as well as well as other Government agencies such as the national and county governments should strive to enhance good working environment for teachers to enhance motivation and job satisfaction hence reducing teacher turnover intentions. This should be through improvement of school infrastructure, teacher recognition and appreciation even when students have not performed well. The study also recommends that both the ministry of education and the Teachers Service Commission involve teachers in formulating of some of the policies that may adversely affect them. For example policies like performance appraisals, and performance contracting should be friendlier to the teachers and mainly be aimed at enhancing their job performance and not to be used for reprisals. This will encourage teachers to be part of the policies and therefore reduce dissatisfaction and lower turnover intentions.

\section{References:}

1. Achoka, J.K., Poipoi, M.W.,\& Sirma, L.M. (2011).Motivational factors influencing public secondary school teachers to join teaching profession in Busia district,Kenya.International journal of current research, Vol.3(4),059-068

2. Alreck, P.L.,\& Settle, R.B.(2004).The Survey Research Handbook. New York:McGraw-Hill.

3. Buckley, J., Schneider, M., \& Shang, Y.(2004).The effects of school facility quality on teacher retention in urban school districts. Washington D.C: National Clearing House for Educational facilities, Chapman

4. Deal, T.E., \& Peterson, K.D. (2002), Shaping school culture fieldbook; San Francisco; Jossey Bass.

5. Gyezaho, M. (2014). Individual, organizational factors and Teacher Turnover Infections among primary schools in Mbarara District. Unpunished master Arts Dissertation, Makerere University, Uganda. 
6. Farren, C. (2008).Managers. A key factor in employee retention and engagement. (Online available) http://www.mastery works.com. $(06 / 02 / 016)$

7. Finlayson, M .(2003). Improving the wellbeing of teachers in Scotland; Scott education journal, 87(1), 18-19

8. Folajimi, O.M.(2009).Teaching profession and factors affecting teaching profession in Nigeria.A Tee 403 Report. Retrieved on Decmber13, 2017 from http://neocgroup.com/atesui.com/printer\%20 Fiendly\%20versions/TEACHING \%20PRESSON.pdf.

9. Frese, M,(1985).Stress at work and psychometric complaints: A causal interpretation; Journal Applied Psychology, 70,314-328

10. Freyermuth. (2007).Retaining Employees in a tightening Labor Market, RSM. McGladrey www.cfo.com/ white papers /index .cfm/ display whitepaper $/ 10308654$ ? Topic id $=10$ 2040327-22k

11. Gatsinzi, P., Jesse, R., \& Makewa, L.N.(2014).Work related variables in teacher motivation Gasabo District, Rwanda. Journal of Education and Trining.vol.1, 2

12. Gay,L.R., Mills, G.E., \& Airasian, P. (2009). Educational research: competencies for Analysis ( $9^{\text {th }} e d$ ). New Jersey: Pearson Education.

13. Grisson, J. A.(2011).Can good principals keep teachers in disadvantaged schools? Linking principal effectiveness to teacher satisfaction and turnover in hard to staff environment. Teachers College Records, 113(11)2552-2585 14.Guin, K. (2004).Chronic teacher turnover in urban elementary schools. Education policy analysis archives, 9,42.

14. Handlesman, J.(2009). Understanding and Remedying Employee Turnover. Available at www.toolkit.com/news/news detail.aspxnid 38 turnover

15. Harris, K., Harris, R.,\& Eplion ,D. (2007). Personality, leader member exchanges and work outcomes. Journal of Behavioral and Applied Management, 8, 92-107

16. Henkins , A.B.,\& Holliman, S.L.(2009).Urban Teacher Commitment. Exploring associations with organizational conflict, Support for Innovation and Participation; Urban Education, 44(2) ,160180.http://dex.doc.org/10.1177/0042085907312548

17. Horng, E.L. (2009) .Teacher tradeoffs. Disentangling teachers' preference for working conditions and students demographics. American Education Research Journal, 46(3) 090- 717 http://dex.doi.org/103102/0002831208329599

18. Imran,M.(2017).Impact of Intrinsic factors of Motivation on Employees Intention to Leave: A case study of Health Department 
District Okara Punjab, Pakistan. Arabian Journal of Business and Management Review, 7,308

19. Ingersoll, R.(2001).Teacher turnover and teacher shortages. An organizational analysis. American education research journal, 38(3), 499-534.

20. Jesus, Des., \& Conboy,J. (2001). A stress management course to prevent teacher distress. The international journal of educational management 15(3), 131-137

21. Johnson, S.M., Kraft, M.A., \& Papay, J.P. (2012). How context matters in high - need schools. The effects of teachers working conditions on their Professional Satisfaction and their students achievements. Teachers College Record,114(10), 1-39

22. Jong, M.D.,\& Gutteling, C. (2009). Relationship between organizational identity, identification and organizational objectives. An empirical study in municipalities. OH Pub.

23. Jong, M.D.,\& Gutteling, C. (2009). Relationship between organizational identity, identification and organizational objectives. An empirical study in municipalities. OH Pub.

24. Juliet.C.(2010). Factors affecting teacher turnover in private secondary schools in Wakiso district. A master's research dissertation, Makerere University. Kampala.

25. Junaidah,K., Zaimidin, A., \&Nazmi, R. (2010), Research Methodology for Business \& Social Science. University Publication Center (UPENA), UTTM.

26. Kafu,P.A. (2011). Teacher Education in Kenya: Emerging issues, International Journal of Curriculum and Instruction, 1(1), 43-52, Available online at http://www.muk.ac.ke/ijci/

27. Kaur, B., Mohindra and Pankaj, (2013), Antecedents of Turnover Intentions. A literature review, Global Journal of Management and business studies, 3(10), 1219-1230

28. Khan, R.A., \& Qadir, M.I.(2016). Determinants of Teacher turnover intentions in Bharia Schools and Colleges at Karachi. Journal of Business Studies, 12 (1), 198-218

29. Kim, N. (2014).Employee Turnover Intention among Newcomers in Travel Industry. International Journal of Tourism Research, 16, 56-64.

30. Kim, S. (2002). Participative Management and Job Satisfaction: Lessons for management leadership; Public Administration Review, vol. 62. Pp, 231-241

31. KIM, S. (2012). The Impact of Human Resource Management of State Government IT Employee Turnover Intentions. Public Personnel Management, 41(2), 257-279. 
32. Koech, S.J., Tikoko, B.J.,\& Chemwei, B.(2014).Institutional factors that influence teachers' turnover in public secondary schools in Baringo County, Kenya. International Journal of Education and Resaerch, 2(3), 20-39

33. Krishman, S.K.,\& Singh,M. (2010). Outcomes of intentions to quit of Judean Professionals. Human resource management, 49(3):28-36

34. Kwenin, D.O.(2013).Relationship between Work Environment, Career Development Opportunities and Employee Retention in Vodafone Ghana Limited. Global Journal of Human Resource Management, Vol.1(4), 1-9

35. Loeb, S., Darling-Hammond, L,\& luczak, J.(2005). How teaching conditions predict teachers turnover in California schools. Peabody Journal of Education, 80 (3), 44-70.

36. MacDonald, L..(2012)..Remuneration and Employee Turnover. Available at file/Documents and settings/admin/desktop/info-8669262doremuneration

37. Mampane, P.M. (2012). The Teacher Turnover Crisis: Evidence from South Africa. Business Education \& Accreditation, 4(2), 73-83

38. Markova, H. \& Ford, P.M.(2011).Human Resources Management (5th ed).McGraw- Hill, New York.

39. Mbah, S., \& Ikemefuna, C. (2011). Job satisfaction and employee turnover intentions in total Nigeria, PLC, Lagos. International journal of humanities and social science, 2 (14), 275-287

40. McCoy, L.P.(2003).It's a hard job. A study of novice teachers. Perspectives on why teachers leave the profession. Current issues in education,6(7).Retrieved on 19/12/2017 from http://c.i.e.edu.asu.edu/volume6/number7/wakeforest

41. Mugenda, O.M.,\& Mugenda, A.G.(2003). Research methods: Quantitative and Qualitative approaches .Nairobi: Acts Press.

42. Muguongo, M.M., Muguna, A.T., \& Muriithi, D.K.(2015).Effects of Compensation on Job Satisfaction among secondary school teachers in Maara Sub-County,Tharaka Nithi County, Kenya. Journal of Human Resource Management, 3(6), 47-59

43. Mutune, J.M., \& Orodho, J.A.(2014).Teachers' turnover. What are the explanatory variables in public secondary schools in Mbeere south sub- county, Embu County, Kenya? Journal of humanities and social sciences, 19,(12), 11-24.

44. Mwamwenda, T.S.(1995).Job Satisfaction among secondary school teachers in Transkei. South African Journal of Eduction, vol.15, pp8487 
45. Ng'ethe, J.M. (2013). Determinants of academic staff retention in public universities in Kenya. PhD thesis, Jomo Kenyatta University of Agriculture and Technology.

46. Nyamubarwa, W. (2013).I am considering leaving soon"- turnover intentions of Academic librarians in Zimbabwe. Journal of business administration and education, volume 4, no.12013-79-90 of manpower 22(7), 600-624.

47. Oketch, M., \&Ngware. M.W. (2012). Urbanization and education in eastern Africa. African population and health research center. ISBN 978-9966-21-175-0

48. Olunlade, R.O.(2012).Managing Employee Compensation and Benefits for Job satisfaction in Libraries and Information Centers in Nigeria. Available http://unllib.unl.educ/LPP/

49. Ongori, H.(2008).A Review of the Literature on Employee Turnover.African Journal of Business Management, 1(3),1-54

50. Orodho, A.J., Waweru, P.N., Ndichu, \& Nthiguri. (2013). Basic education in Kenya. Focus on strategies applied to cope with school based challenges inhibiting effective implementation of curriculum. International journal of education and research, 1 (11), 1-10

51. Parasuraman, B.,Uli, J., \& Abdullah, M.M. (2009).Job Satisfaction among Secondary School Teachers. Journal kemanusiaan, 1(3), 10-18

52. Purani, K., \&Shadev, S. (2008). The moderating role of Industrial Experience in the job satisfaction intention to leave Relationship: An Empirical Study among salesmen in India. Journal of Business and Industrial Marketing, 23(7), 475-485. hppt://dx.doi.org/org/10.1108/08858620810901239

53. Quick, J.C.\& Nelson, D.L (2011). Principles of organizational behavior, realities and Challenges ;South eastern . Cengage learning, Singapore.

54. Sergiovanni, T.J.(2009).The Principalship. A reflective practice perspective. $\left(6^{\text {th }} e d\right)$ Texas; Pearson Education, inc.

55. Sharma, J.P., \& Bajpai, N.(2010). Organizational commitment and its impact on job satisfaction of employees: a comparative study in public and private sector in India. International Bulletin of Business Administration, 13 (2), 97-118.

56. Souza-Posa, A., \&Hennenberger, F. (2004). Analyzing job mobility with job turnover intentions: An International Cooperative Study. Journal of economic issues, 38(1), 113-137.

57. Suleiman A, A.,\& Matsom, A.(2013).Employee Dissatisfaction and Turnover Crisis in the Malaysian Hospitality Industry. International Journal of Business and Management, 8(5), 62-71 
58. Susu, K.(2008).Factors contributing to teacher turnover in primary schools in sigor division, Bomet district. (Un published masters thesis) Kenyatta University.

59. Tarmizi, A.N. (2008).Quality of Work Life and Turnover Intentions: The Mediating Effects of Career and Organizational Commitment, Masters thesis Business Administration,USM. Retrieved on30/10/2017,URI:http://eprints.usm.my/id/eprint/25416

60. Waleed, A. (2011).The Relationship between Human Resource Practices and Employee Retention in Public Organizations. An Exploratory study conducted in the United Arabs Emirates. PhD Thesis, Edith Cowan University.

61. Schields, P.M., Esch, C.E., Humprey, D.C. Young, V.M Gaston, M., \& Hunt, H. (1999). The status of teaching profession: Research findings and policy recommendations. A report to the teaching and Carlifornia's future task force. Santa Cruz, C.A: The center for the future of Teaching and Learning.

62. Wambugu,T.W.,\& Busienei,J.R.(2015).Factors leading to Job Satisfaction of public secondary school teachers in Nairobi County, Kenya. Strategic Journal of Business and Change Management, 2(122), 1988-2008.

63. Wasserman, B., \& Yehoshua, G. (2016).Relationship between the principal's Leadership style teacher motivation. International Journal of Learning, Teaching, and Educational Research, 5(10), 180-192.

64. Zahra, S., Irum, A., Saad, M.,\&Chishti ,A.(2013).Job satisfaction and faculty turnover intentions. A case of Pakistan University. Journal of business and management, vol. 9 issue 2.

65. Zeytinoglu, L.U., \& Denton, M. (2005.) Satisfied workers retained; workers effects of work, and work environment on turnover. Prentice Hall 